\title{
KierkegaARD, Martensen, and the Meaning of Medieval Mysticism
}

\author{
George Pattison \\ University of Glasgow, Scotland, UK
}

\begin{abstract}
Although it is not known whether Kierkegaard read Martensen's 1840 study on Meister Eckhart, this small book provides a useful point for identifying key issues in Kierkegaard's relation to speculative idealism and mysticism. Following a summary of Martensen's text, the article argues that although Kierkegaard rejects speculative idealism's reading of medieval mysticism, his own work reflects in devotional idiom some of the same themes we find in Eckhart and even, quite specifically, in Martensen's Eckhart.
\end{abstract}

Key words: Speculative theology, mysticism, God, Martensen, Eckhart.

\section{Resumen}

Aunque no se sabe si Kierkegaard leyó el trabajo de Martensen de 1840 sobre Meister Eckhart, esta pequeña obra nos ofrece una herramienta útil para identificar planteamientos clave en la relación de Kierkegaard con el idealismo especulativo y el misticismo. Después de hacer un resumen del escrito de Martensen, el presente artículo sugiere que si bien Kierkegaard rechaza la interpretación del idealismo especulativo sobre el misticismo medieval, su propia obra refleja, en términos devocionales, algunos de los mismos temas que encontramos en Eckhart e incluso, de forma más específica, en el Eckhart de Martensen.

Palabras clave: teología especulativa, misticismo, Dios, Martensen, Eckhart.

\section{Introduction}

It is now commonplace to note that Kierkegaard's literary career involved a mildly obsessive rivalry with his five-year older contemporary Hans Lassen Martensen. Their paths were, it seems, destined to cross repeatedly from the time when Kierkegaard hired Martensen as a private tutor to work 
on Schleiermacher (1834), through his attendance at the lectures in which Martensen introduced Hegelianism into Danish theology (1837-8), through literary rivalry associated with the Heiberg circle (1837-40), right through to when Martensen became the prime target of Kierkegaard's final 'Attack on Christendom' (1854-5). Throughout this time, it is clear that Kierkegaard closely tracked Martensen's work-from this cry of misery over Martensen having published an article on Faust ${ }^{1}$ through to his outrage at Martensen's memorial eulogy over Bishop Mynster in 1854. Yet he seems never to have explicitly commented on Martensen's 1840 book Meister Eckhart: A Study in Speculative Theology. ${ }^{2}$ In fact, he seems never to have explicitly mentioned Meister Eckhart at all, although it is clear that he read many works in which Eckhart is referred to and was certainly familiar with works strongly influenced by Eckhart including Johannes Tauler and Johann Arndt and there are passages in Kierkegaard's devotional writings that to some extent converge with the kind of mystical themes associated.

Did Martensen's book and its subject, Eckhart, simply pass Kierkegaard by, or is this work in some way reflected in the authorship, perhaps in a "silent way," as Peter Šajda has argued? It seems implausible that Kierkegaard didn't know of Martensen's book and improbable that he didn't read it. In an intriguing essay Šajda suggests that the portrait of the aesthete "A" offered by Assessor Vilhelm in part reflects Martensen's characterization of the mystic, as found in the book on Eckhart. ${ }^{3}$ This is not impossible. Yet in light of the growing awareness of significant commonalities between Kierkegaard's religious writings and the mystical tradition broadly understood as well as of the importance of the kind of speculative theology represented by Martensen, the book on Eckhart might seem to provide a useful point

${ }^{1}$ Cfr., SKS 27, Papir 244 / JP 5, 5225.

${ }^{2}$ An English translation is found in Thompson, C. L., and Kangas, D. (trans.), Between Hegel and Kierkegaard. Hans L. Martensen's Philosophy of Religion, Georgia: Scholars Press 1997, pp. 149-242. Further references will be given in the text as ME followed by page number.

${ }^{3}$ Cfr., Peter Šajda, "Meister Eckhart: The Patriarch of German Speculation who was a Lebemeister: Meister Eckhart's Silent Way into Kierkegaard's Corpus" in Kierkegaard Research:Sources, Reception and Resources, Vol. 4: Kierkegaard and the Patristic and Medieval Traditions, ed. by Jon Stewart, Farnham: Ashgate 2008, pp. 237-53. Šajda also usefully sets Martensen's Eckhart book in the context of contemporary speculative theology. Cfr., Peter Šajda, "Martensen's Treatise Meister Eckhart and the Contemporary PhilosophicalTheological Debate on Speculative Mysticism in Germany" in Hans Lassen Martensen. Theologian, Philosopher and Social Critic, ed. by Jon Stewart, Copenhagen: Museum Tusculanum 2012, pp. 47-72. 
of reference for teasing out new aspects of Kierkegaard's relation to both mysticism and speculative theology. Kierkegaard indeed left no notes on the work, but it is by no means difficult to see how he might have responded to it and why his disagreement with Martensen might have led to his not pursuing Eckhart as a source of spiritual understanding, despite his interest in several of Eckhart's followers.

In this essay I shall therefore begin by offering a brief summary of Martensen's book in the overall context of early nineteenth-century receptions of Eckhart's work; next, I shall consider how the book highlights aspects of Martensen's thought that would especially have displeased Kierkegaard; and, finally, I shall consider how, nevertheless, it is not unreasonable to talk of an "Eckhartian" current in Kierkegaard's work. This is not to argue that Eckhart really was a "hidden source" of Kierkegaard's key religious ideas. Kierkegaard's thought was an ocean criss-crossed by multiple currents and not all of them flowed in the same direction. To identify one of these many currents as "Eckhartian" is therefore no more than to observe one small part of a complex phenomenon-yet it is, I suggest, an important part.

\section{Martensen on Eckhart}

The history of publication of Martensen's work itself has Kierkegaardian echoes in that it was originally conceived as a doctorate to be submitted for examination to Copenhagen University. Like Kierkegaard's Concept of Irony, however, it was written in Danish, not Latin, and as Kierkegaard would do shortly afterwards, Martensen therefore had to petition the King to have it presented in Danish. In the event, however, he actually submitted it to Kiel University, so that the petition did not proceed. In English translation the title appears as Meister Eckhart. A Study in Speculative Theology. This is certainly accurate as far as the content of the work goes, but (as the translators note in their Introduction) the literal translation of the sub-title is "A Contribution to illuminating the Mysticism of the Middle Ages." And although Meister Eckhart is the main focus of the work, Martensen himself quickly makes clear that he will also be considering the continuation of the Eckhartian tradition in Tauler, Henry Suso, and the Theologica Germanica.

Although works by Eckhart are now widely available in both scholarly and popular editions and selections and he is often seen as one of the representative figures of medieval thought and of Christian mysticism more gen- 
erally, his work and reputation only started to emerge from obscurity in the very late eighteenth and early nineteenth centuries. Although some work by Eckhart had been mistakenly credited to Tauler or recycled in authors such as Arndt, allowing him to have had some unacknowledged influence, it was only with the Romantic return to the medieval past (a return coloured, in the case of Eckhart, by a certain nationalistic interest) that a significant body of texts became formally identified as genuinely Eckhartian. At the same time as the work of early Eckhart textual research, Eckhartian themes begin to be taken up by key thinkers of German Idealism, including J. G. Fichte, Franz von Baader (whose work Kierkegaard was reading in his student years), Hegel, and Schopenhauer. There was an explicit recognition that the kind of mystical vision articulated in Eckhart resonated with idealism's understanding of the divine-human relationship, a resonance summed up for Hegel in Eckhart's line that "the eye with which I see God is the same eye with which God sees me" (Hegel had in fact been introduced to Eckhart by von Baader). ${ }^{4}$ Now this may have involved a significant misreading of Eckhart's own text, although it is not to the purpose of this article to pursue that issue further. Nevertheless, it is clear that by 1840 there was a widespread sense that Eckhart in some way anticipated the more fully developed speculative theology developed in German Idealism.

In the light of this situation, it would be easy to assume that Martensen (as Kierkegaard tends to depict him) was doing no more than popularizing others' ideas. However, at the same time it should be said to Martensen's credit that his was amongst the very first monographs to be dedicated to Eckhart's work. Noting Kierkegaard's aspersions, Cyril O' Regan comments on Martensen's work that, in comparison with Baader, his 'reading of Eckhart is by far the more focused, his method considerably more "scientific" (wissenschaftlich), and his ability to make distinctions between genres and levels of discourse much more developed'.5 O'Regan therefore sees Martensen as a significant milestone in the reception of Eckhart in the nineteenth century.

Martensen himself was aware of the context in which he offered his 'contribution' and starts his study by locating the growing interest in Eck-

${ }^{4}$ On German idealism as one of the sources for Kierkegaard's knowledge of mysticism see Marie Mikulova Thulstrup, "Kierkegaards møde med mystik gennem den spekulative idealismen,” Kierkegaardiana, X, 1977, pp. 7-69.

${ }^{5}$ Cyril O' Regan, "Eckhart Reception in the $19^{\text {th }}$ Century" in A Companion to Meister Eckhart, ed. by Jeremiah M. Hackett, Leiden: Brill 2013, p. 657. 
hart in a broad history of ideas context. Where the Enlightenment had dismissed medieval mysticism as essentially irrational, Romanticism took a more positive interest, he observes. However, Romanticism valued mysticism precisely because it was "ineffable and beyond reason" (ME, p. 152). Against this Romantic view Martensen asserts that mysticism is closely related to both science and philosophy and is not just a matter of feeling "but is itself a form of speculative theology" (ME, p. 152). In particular, the kind of mysticism that appeared in the fourteenth and fifteenth centuries in Germany was "the first form in which German philosophy appears in history" and, as such, the first attempt "to sublate the contrast within reflection between faith and knowledge" (ME, p. 152). Of all these mystics, Eckhart is "the patriarch" (ME, p. 153) of this 'spiritual explosion' (ME, p. 155).

Acknowledging the then very limited knowledge of Eckhart's biography (a set of limitations that will have significant consequences for Martensen's reading, as we shall see) as well as the uncertainty of the textual tradition, Martensen portrays Eckhart's time as one in which the Church was on the edge of collapse and in which "spiritual persons" were therefore "forced to retire into themselves" (ME, p. 156). At the same time, this was a situation that favoured the growth of vernacular languages and preachers such as Eckhart therefore had an important role here too, being (as Martensen says) "poets of prose" (ME, p. 156). In this time of ferment, the lack of any prospect for the emergence of a new order meant that the mystic turned away from history into the immediate "now" of contemplation, seeking in imagination what couldn't be found in life and anticipating an eschatological fulfilment that was lacking in the present. The mystics' teaching that "God is the formal essence of everything" and that "every spiritual person was a God-human" (ME, p. 158) drew official condemnation, as did related movements such as the "eternal gospel" of the radical Franciscans and the heresy of the Free Spirit, often (though Martensen thinks wrongly) associated with Eckhart.

After this general contextualization, Martensen offers a number of short selections from Eckhart's work, assuming (with justification) that his readers will be unfamiliar with them. Then he turns to the major part of the work, namely, a presentation and analysis of Eckhart's main themes.

The first of these themes has the general heading "Mystery". It begins by looking at the charges of acosmism, atheism, and pantheism often levelled against the mystics. However, Martensen is not willing to regard these as purely negative terms. On the contrary, "pantheism is not just the normal 
living element of philosophy, but also of religion" since it undermines the rigid distinction between finite and infinite: "God's all-permeating substantiality is the characteristic idea of pantheism", he writes (ME, p. 176). Crucial here is the Hegelian distinction between representation (Vorstellung) and thought, that is, between thinking of God in what is sometimes translated as "picture-thinking" and thinking of God purely conceptually. The charge of pantheism confuses these levels, since it imagines mysticism to be representing God as materially identical with all things rather than grasping an identity that is purely and properly for thought alone. Conceptually, Martensen appears to see at least some justification in the claim that "God cannot stand in relation to something outside of Godself, but only in a relation to God's own self" (ME, p. 177).

God's self-identity as the true principle of being entails an effective annihilation of the world as a proper object of contemplation in itself, a move evident in the mystics' preference for the via negationis. But this is also 'the pre-school in which consciousness is weaned [i.e., from materialism and mere representation] in order to contemplate life sub specie aeterni (ME, p. 177) — this last being a phrase that will have particular significance in Kierkegaard's later polemics against speculative idealism (a point to which we shall return). Mystical theology thus looks beyond images to the pure "Essence" (which Martensen says is the most important name for God amongst mystics) or "pure intelligence" that in its utter simplicity is equally well describable as "the pure nothing" or "infinite freedom" (ME, p. 178).

As such acosmism denies the world's independence of God and this denial is especially concentrated in the subject's (the I's) own relation to God. To obtain the vision of the pure essence of God 'Human beings must therefore die away from the I', becoming divested "of all images", and living "without a why," in a state of entire "poverty" (ME, 180). ${ }^{6}$ The issue is a practical one, namely, the quest for salvation or blessedness that the mystic thinks can only be found in "absolute identity" with God. In these terms, mystical literature is "an instruction in the blessed life", a point that prompts Martensen to draw a parallel with Fichte's Anweisungen zum seligen Leben -although the mystics are writing in and for a monastic context (ME, p. 182). The mystic quest is therefore generated by an "infinite selfconcern" such that the annihilation of the I is envisaged primarily and precisely as the condition of an "eternal rebirth" (ME, p. 182).

${ }^{6}$ This time the expression "to die away from" anticipates something Kierkegaard will affirm, in his view, at least, against the speculative abstraction from self. 
Martensen next considers mystical teaching under the rubric "atheism," although the shift is not entirely clear as regards the main course of the argument. Here he references Eckhart's prayer to God to free him from God. This God who can free us from God is in effect "a third," distinct from theism's "God" and from the world. It is the Urgrund or "originary ground," not as a logical idea but as "an ungrounded sea of light in which all colors and determinations are abolished" (ME, p. 183) and which can, as such, only be spoken of apophatically.

However, Martensen suggests that "essence is only truly essence in its phenomena" (ME, p. 184) and that "a mystery without spirit and revelation is a contradiction" (ME, p. 185). Only when there is revelation can there be genuine knowledge of God. Mysticism is not entirely lacking an awareness of needing to give determinate content to the idea of God but it does not really develop the connection between essence and appearance. In other words, mysticism lacks "mediation, or the concept" — again terms that Kierkegaard will pick up on in his attack on speculation.

Thus far, mysticism offers only the immediate or subjective unity of religion and philosophy. It is correct to affirm the identity between divine and human, but ultimately it affirms it only religiously and not philosophically since it fails to reflect sufficiently on its own act of seeing and therefore lacks "internal self-differentiation" (ME, p. 187).

This shortcoming also connects to the way in which, in the "mystical night," there is no real distinction between Christian and non-Christian mysticism. But the point of departure for all Christian theology is the "richness of thought" found in revelation (ME, p. 189). In fact, even if the mystic is not aware of it, "the mystical "nothing" achieves its particular significance from the "something," i.e., the revelation, which precedes it', namely, Christian teaching on the Trinity, creation, Incarnation, sin, and redemption (ME, p. 189). For Christianity this is not just a matter of liberating thought from the illusion of difference but "the restoration of existence to its groundrelation" (ME, p. 189) (another Kierkegaardian theme, it might seem). For finitude is "the heart of the matter in all religion... the proper cross of philosophy" (ME,190), Martensen states, evoking the Lutheran symbolism of the cross and rose, which he presents as an antidote to all "Oriental" or Neoplatonic mysticism.

Christian mysticism moreover requires the imitation of Christ. But, once more, the mystic seems to be right in seeing that this is not just a matter of moral improvement "but a real, inward, and essential process of Chris- 
tification" (ME, p. 191). Versus all orientalism, Augustine directed Western Christianity to the concrete dialectic of sin and redemption. What this leads to, in Martensen's view, is that "Christification" is epitomized in the term Gemyt, which he describes as the state in which "the soul [is] collected into itself; it is the life and stirring as of the soul's internal infinity, the human person's esoteric personality" (ME, p. 192). As such it manifests the coincidence of absolute truth and empirical life, "experience" in the richest sense of the word, corresponding to the manifestation of God in the concrete life of an individual human being.

Martensen sees the mystic's cultivation of such Gemyt as in opposition to scholasticism's “atomistic dialectic" and as something distinctively German"Roman" mysticism by way of contrast is "bound to forms of representation and feeling; thought cannot achieve a breakthrough as such" (ME, 194). Against the "prudently reflecting" mood of scholastic mysticism, German mysticism is "speculative" and "actual": "German mysticism is the West's retrieval of the speculation of Dionysius, the Areopagite," he states (ME, p. 196).

Again, Gemyt will be a term favoured by Kierkegaard, as when in The Concept of Anxiety he connects it with seriousness or earnestness. ${ }^{7}$ However, we should also note that Martensen's contrast between mysticism and scholasticism clearly reflects his lack of historical knowledge about Eckhart, as well perhaps as a desire to recruit Eckhart for a "Protestant" history of ideas. In his biographical notes he seems to know only that Eckhart studied in Paris, not that he held a senior teaching position there, and although he does comment on Eckhart's administrative roles in the Dominican Order he does not give much weight to them. Essentially he emphasizes the elusiveness of Eckhart's historical identity. Today, however, it is clearly not possible to distinguish between Eckhart and scholasticism in this way. If Eckhart was a vernacular preacher, he was also a scholastic, operating at a senior level in the very heart of scholastic culture.

Next follows Martensen's second main section: "Revelation." We have, of course, already seen that he requires mystical union to be supplemented by revelation and, in fact, he finds this also in Eckhart's own teaching: Eckhart, he says, "live and moves in the revealed God just as deeply as he is buried in the hidden God" (ME, p. 197). If medieval mysticism knows of the unity of God and world it also knows of their difference, especially in the cases of Eckhart and Suso. In a relatively extensive commentary on Suso's Eternal Wisdom, Martensen shows that the author knew both union and

${ }^{7}$ CA, 147-9 / SKS 4, 446-451. 
difference and had a "revelation-consciousness" lacking in the pantheistic sects wrongly associated with Eckhart and his followers-although, again, the mystics' lack of self-reflection meant that they were not aware of their own affinity to pantheism.

The mystics' grasp of revelation in the light of the experience of union meant that (as against "scholastic supernaturalism") they had an "immanental understanding of dogma" that enabled them to see the connection between dogma and personality. The human being is the purpose of creation, not as a (scholastic) "final cause" but so as to enable a "love-relation" to God. For the God-relationship is not a causal but a substantial relationship. This is the speculative truth of mysticism: that there is a fundamental identity between God's being and God's self-communication as the goodness of all that is good. In these terms, God cannot be God without a world, as illustrated by Angelus Silesius' well-known lines "I know that without me God could not for an instant live, / Were I to perish, God must necessarily give up the ghost" (ME, pp. 204-5). Conversely, "the world only exists so that God can be revealed" (ME, p. 205). Noting analogies to Fichte, Martensen sums up: "God's self-revelation in and for the world is a moment in God's self-revelation" (ME, p. 206). However, whilst the logic of this structure of world- and self-revelation means that the world must be "other" than God it also requires there to be a point of identity within the world in which God can know Godself. This is the human soul, of which Martensen writes that "The reason for the gloriousness of the soul lies in the ideal nature of self-consciousness and freedom, in thinking, which is the soul's substance. In knowledge the soul is made participatory in God's nature" (ME, p. 207). The circular dynamic of unity and difference find dogmatic expression in the doctrines of the Trinity and of creation. This, Martensen cautions, risks confusing the unity-and-difference of the Father and the Son and of God and the world. Sometimes the mystics make this confusion. Nevertheless, it is precisely their service to the development of dogma to have seen creation and Incarnation as 'moments in the Trinitarian process' (ME, p. 212).

The identity of Christ and the soul, Christ in us, is further understood as the soul's own deification and, again, this distinguishes the mystical tradition from Catholicism. Catholicism is only able to see the identity of divine and human via artistic representation and as such something external, something to behold-but not (as in the mystics) to be! Likewise, the mystics go in the opposite direction from that other great medieval movement, the Crusades. Yet if the medieval Church (for Martensen, "Catholicism") 
erred by making the external (art, the Holy Land) the object of devotion, the mystics too erred by undervaluing the social aspect of Christianity, what Martensen calls its "social eye" (ME, p. 224) and the necessary universality of Christian teaching.

This brings Martensen to his third and final main section, "The Highest Good and Virtue." This develops further themes with which we are by now familiar. For Christian morality is not (as commonly understood) "an empty concept concerning God's will" but the call to actualize God's essence. The statement that "the human being shall do good" means "the human being shall realize God" (ME, p. 226). What God is and what God commands are one and the same: "God commands love, God is love" (ME, p. 227). As in relation to the preceding topics we see a mixed judgement on the mystics. The requirement of realization remained "only a principle" for the mystics, somewhat as in the Stoics and in Kant. Yet Martensen also seems to see particular significance in their understanding of the relationship between active and passive reason since in their portrayal of passive reason they show how this can give birth to the eternal Son in the soul, as, as it were, "a mother of God" (ME, p. 231). It is also unfair to say, as was often said, that they were indifferent to the salvation of others, as manifest in their preaching work-but normally "The life about which they discourse is the monastic ideal" (ME, p. 234). Nevertheless, they are in some ways predecessors of the Reformation in their stress on freedom, inwardness and the living word. In Luther the mystical union is transformed into justification by faith, understood as "the true point of identity between God and the sinful human person” (ME, p. 236)—although in the mystics themselves the striving for identity is still affected by Catholic Pelagianism.

Martensen concludes with a discussion of the relationship between Eckhart and Boehme, another important mystical source in German Idealism and a thinker to whom Martensen would dedicate his final book some forty years later.

\section{Martensen's Eckhart and Kierkegaard's (Possible) Eckhart}

Let us suppose, as seems likely, that Kierkegaard read Martensen's "contribution" - and even if he did not, it is a text that usefully condenses a number of the central themes of speculative theology to which Kierkegaard was attentive from his student notes through to Concluding Unscien- 
tific Postscript. That is to say that Martensen's Meister Eckhart can have a heuristic value for our reading of Kierkegaard even if we can only guess at the historical basis of the connection. But a key element in its value is not only how it helps clarify Kierkegaard's relation to speculative theology but also the way in which it shows how the question of speculative theology was bound up with the question of mysticism and therefore, more broadly, of religious and specifically Christian experience. In these terms, the pattern that emerges from reading Meister Eckhart in a Kierkegaardian perspective is one in which, on the one hand, the speculative element that Martensen finds in Eckhart is precisely what Kierkegaard will (sometimes violently) reject, whilst the element of Christian experience relates closely to what Kierkegaard himself will portray as the apex of devotional life.

Let us look at these two tendencies more closely.

Martensen, as we have seen, follows Hegel in seeing Eckhart as a forerunner of modern speculation. In these terms, although he does indeed use the word "experience" he strongly dissociates Eckhart from the kind of experiential found in Romanticism, where the emphasis is on feeling. Instead, the value of such experience is as a gateway to knowledge, specifically conceptual knowledge rather than the kind of knowledge associated with "mere" representation (Vorstellung). At its maximum, such knowledge gives us a view of God, the world, and the human condition sub specie aeterni. At the same time, medieval mysticism only takes a preliminary step towards full speculative knowledge since, due to its failure to reflect on its own subjective consciousness of God, it does not cognize the full dialectical interconnection of divine and human. It understands the point of identity with God but does not develop the way in which identity and difference cohere in a more dialectical unity. As regards a full speculative development of Christian dogmatics, it, as it were, opens the way to a thoroughly dialectical knowledge of the doctrines of God, the Son, creation, Incarnation, sin, and redemption but it does not itself pursue that way to its intellectual end.

Eckhart was not, of course, Martensen's sole or even primary source for the idea of speculation. In the late 1830s speculative theology had become a highly influential movement in ideas, substantially overlapping with what has been called "Right" Hegelianism, though with an emphasis on the necessarily personal nature of theological truth that is lacking (or at least not emphasized) in Hegel. As such, speculation sets out from the a priori structures of consciousness and from these deduces the manifold of the world in its appearance. Yet, at the same time, these a priori structures provide 
a basis from which we are now able to look back and trace the historical movement that made it possible for just this speculative insight to find its true form in just this contemporary historical moment. "We" do in fact understand speculation better than Eckhart did, but by establishing a historical genealogy running back beyond the Reformation modern speculation is shown to be more than a flash in the pan but to have a long-term historical significance and to be the fruit of the defining tendencies of the Western tradition. As we have seen, Martensen's grasp of the actual historical context of Eckhart's life and work was (partly through no fault of his own) deeply flawed and, as a historical study, Meister Eckhart is by no means a success. What is important, however, is to understand why it mattered to Martensen that he should seek to resource contemporary speculative theology by returning to its earlier forms.

Speculative theology was, of course, deeply antithetical to Kierkegaard. His most fully developed critique is set out in Concluding Unscientific Postscript, the last of the first round of pseudonymous works that were aimed at undermining the foundations of contemporary intellectual life and culture. But, as I have demonstrated elsewhere, the key elements of this critique and its vocabulary was already being articulated in the journals in the period 1837-8 in Kierkegaard's responses to a range of primary sources of speculative theology including J. G. Erdmann, Karl Rosenkrantz, and, not least, the lectures by Martensen himself that made speculation suddenly fashionable amongst Danish theology students. ${ }^{8}$ In the Postscript itself, it is precisely the very notion of speculation (i.e., cognition based on reflective vision) that is repeatedly seen as the cardinal error of Hegelianism and the idea that human beings are capable of seeing the world sub specie aeterni is ridiculed as the most obviously ridiculous outcome of pretensions to a speculative knowledge that is plainly beyond human capacity. ${ }^{9}$ In other words, it is precisely what Martensen sees as Eckhart's most important contribution to the history of ideas that, if true, would put Eckhart in the same category as Hegel and Martensen himself from a Kierkegaardian point of view. If Kierkegaard did read Meister Eckbart and if he was persuaded by Martensen's presentation about the speculative character of Eckhart's thought (and he would have had very little by way of alternative perspectives to draw on),

${ }^{8}$ For a fuller discussion see George Pattison, Kierkegaard and the Theology of the Nineteenth Century, Cambridge: Cambridge University Press 2012, especially Chapter Three, "Speculative Theology," pp. 30-56.

${ }^{9}$ CUP 1, 301-309 / SKS 7, 274-281. 
then we can certainly see why he would have had little incentive to spend more time getting to know this "patriarch of mysticism."

But there is another side to the story. We have noted several points at which Martensen's Eckhart anticipates themes that will become positive elements in Kierkegaard's own thought: the cultivation of Gemyt, the infinite self-concern of the I in its own existence as prior to and more fundamental than its life in community, and the annihilation of that same I in the Godrelationship as the condition of its rebirth. So too, mutatis mutandis, Martensen's highlighting of the importance of imitation as something more than a merely moral effort to "do good" —although Kierkegaard's notions of imitation would seem scarcely to have allowed for "Christification," since what is characteristic of the Kierkegaardian imitator is that he repeatedly discovers his failure to live up to the ideal and his consequent reliance on grace.

If we turn to the series of excerpts from Eckhart's sermons, even more points of contact come into view. Let us consider just three examples, which are not exhaustive.

"Whoever, in the midst of time, has set their heart on the eternal, in him or her is the fullness of time" (ME, p. 164). "God gives Godself in all God's gifts" (ME, p. 165). "If you seek God and something else besides God, then you will not find God; but if you seek God alone, then you will find God and the whole world along with God" (ME, p. 165).

These are all points that we find at crucial points in Kierkegaard's religious writings and that can therefore be seen as major themes of Kierkegaard's religious thought. Thus, the idea of the moment as the presence of the eternal in time is developed conceptually in The Concept of Anxiety but recurs at many moments in the upbuilding discourses, climaxing in the 1849 discourse on joy in which Kierkegaard defines joy as being entirely in the present as God, though essentially eternal, is entirely present in each now, each "today": "... if you remain in God, whether you live or die, whether it goes well with you or badly, as long as you live and whether you die today or only after seventy years, and whether your death is in the ocean's deepest depths or you are blown into thin air, you are never outside God, you remain, that is, you are present to yourself, in God, and therefore, even on the day of your death, you are today in paradise."10

Likewise, the theme of "every good and perfect gift" coming from God is one of the dominant themes of the discourses, and, for Kierkegaard, the

${ }^{10}$ Kierkegaard, S., Kierkegaard's Spiritual Writings, trans. G. Pattison, New York: Harper, 2010, p. 244. WA, 45 / SKS 11, 48. 
point of the divine gift is precisely that it is not merely external, but a gift in which God is given along with whatever else we are given. Take this passage from the second of Kierkegaard's discourses on James 1. 17:

For what is the Good? It is what comes from above. What is perfection? It is what comes from above. Where does it come from? From above. What is the Good? It is God. Who is it who gives it? It is God. Why is the Good a gift and why is this no figure of speech but the one reality, the sole truth? Because it is from God. For if human beings could give themselves or give each other anything at all, then this would not be the Good nor would it be a gift but would only appear to be so. For God is the only one who can give in such a way that he also gives the condition for receiving the gift. He is the only one who, when He gives, has given already. God gives the power both to will something and to perfect it: He begins and completes the good work in a person. My listener, will you deny that this is something that doubt is unable to reverse, precisely because it is beyond doubt and remains in God? And if you don't want to remain in it, isn't it because you don't want to remain in God, in whom you live and move and have your being? ${ }^{11}$

Now, clearly, what Kierkegaard is saying here is more nuanced than the extremely brief quotation provided by Martensen. Nevertheless, a similar logic is at work: what God gives is the Good, but since it is said that God is the Good, what God gives is, precisely, Godself, so that the one who receives the gift remains in God, living and moving and having their being in God.

The theme that we need to be entirely single-minded if we are to find God is, famously, the dominant theme of the extended discourse "On the Occasion of a Confession," the teaching of which is often paraphrased in the one saying that "purity of heart is to will one thing" and which contains a repeated and insistent criticism of the various forms of double-mindedness—of wanting both God and worldly benefits - that get in the way of such purity.

A perhaps especially striking passage is the next-to-last in which Eckhart describes taking a bucket of water within which he places a mirror and puts it outside in the sun. The sun's light, passing through the water and reflected in the mirror is, as Eckhart puts it, "sun in the sun" (ME, p. 175), commenting that "The soul's reflection is [in the same way] God in God, and yet the soul remains what it is" (ME, p. 175). This curious image offers a key to an important image that recurs several times in Kierkegaard's upbuilding writings. In the last of the Eighteen Upbuilding Discourses, for example, we read:

${ }^{11}$ Ibid., p. 33. EUD, 134 / SKS 5, 137. 
... if he himself is anything [in his own eyes] or wants to be anything, then this something is enough to prevent the likeness [from appearing]. Only when he himself becomes utterly nothing, only then can God shine through him, so that he becomes like God. Whatever he may otherwise amount to, he cannot express God's likeness but God can only impress his likeness in him when he has become nothing. When the sea exerts all its might, then it is precisely impossible for it to reflect the image of the heavens, and even the smallest movement means that the reflection is not quite pure; but when it becomes still and deep, then heaven's image sinks down into its nothingness. ${ }^{12}$

What is curious about this image is that the person (in a variant version in "On the Occasion of Confession," "the heart") both reflects and is transparent to the divine likeness, figured as sunlight. But, normally, we don't think of reflectivity and transparency as compatible. To the extent that a surface reflects light, that same light does not pass (or "shine") through it. Conversely, light that is passing through a given medium is not being reflected by it. Eckhart's mirror in a bucket, however, gives us a concrete way of imagining this, since the sunlight passes through the water to be reflected back from the mirror at its bottom. And in both Eckhart and Kierkegaard, it is clear that the point is to do justice to both the unity of the soul or heart with God and its distinction from God.

The point of drawing these parallels is not to suggest that Kierkegaard was directly inspired by Martensen's text to introduce these themes and images into his own works. There were many other sources from which he could have derived them, including Tauler and Arndt and other spiritual writings mediated by Pietism. ${ }^{13}$ Images of mirroring, light, and reflection are a commonplace of the Christian imaginary and are made much of in illustrated versions of Arndt's True Christianity with which Kierkegaard would have been familiar. So too are exhortations to singleness of intent and God's presence in all that he gives. The specifics of Kierkegaard's sources require another kind of study and, of course, in many cases that work has been or is being done by some of the outstanding scholars working in Kierkegaard Studies. My point here is simply to indicate that of the two lines of reception flowing from Eckhart's thought, the speculative and the mystical, it is clear (1) that Martensen prioritized the speculative and that to the extent that Eckhart's thought was identified with speculation Kierkegaard would have

${ }^{12}$ EUD, 399 (translation adapted) / SKS 5, 380.

${ }^{13}$ On Kierkegaard's spiritual reading see Christopher B. Barnett, Kierkegaard, Pietism, and Holiness, Farnham: Ashgate 2011, pp. 63-107. 
had to reject it, but (2) Kierkegaard's own spiritual reading made him open to a very different, non-speculative tradition of reading Eckhart, whether he himself did or did not make the connection back to Eckhart himself. A curious twist in this tale is that some recent commentary suggests that it is precisely this "spiritual" or devout way of reading of Eckhart that has become most relevant to post-Heideggerian philosophy of religion, that is, a philosophy of religion that has long since abandoned the speculative and metaphysical claims of Hegelian theology. ${ }^{14}$ But seeing all that involves would be another story.

\section{Bibliography}

Barnett, Christopher B., Kierkegaard, Pietism, and Holiness, Farnham: Ashgate 2011, pp. 63-107.

Kangas, David, Kierkegaard's Instant: On Beginnings, Bloomington: Indiana University Press 2007.

_Errant Affirmations. On Kierkegaard's Religious Discourses, London: Bloomsbury, 2017.

Pattison, George, Kierkegaard and the Theology of the Nineteenth Century, Cambridge: Cambridge University Press 2012.

Šajda, Peter, "Martensen's Treatise Meister Eckhart and the Contemporary Philosophical-Theological Debate on Speculative Mysticism in Germany" in Hans Lassen Martensen. Theologian, Philosopher and Social Critic, ed. by Jon Stewart, Copenhagen: Museum Tusculanum 2012, pp. 47-72.

"Meister Eckhart: The Patriarch of German Speculation who was a Lebemeister: Meister Eckhart's Silent Way into Kierkegaard's Corpus" in Kierkegaard Research:Sources, Reception and Resources, Vol. 4: Kierkegaard and the Patristic and Medieval Traditions, ed. by Jon Stewart, Farnham: Ashgate 2008, pp. 237-53.

Thompson, Curtis L., and Kangas, David (trans.), Between Hegel and Kierkegaard. Hans L. Martensen's Philosophy of Religion, Georgia: Scholars Press 1997, pp. 149-242.

Thulstrup, Marie Mikulova, "Kierkegaards møde med mystik gennem den spekulative idealismen,” Kierkegaardiana, X, 1977, pp. 7-69.

${ }^{14}$ Cfr., e.g., David Kangas, Kierkegaard's Instant: On Beginnings, Bloomington: Indiana University Press 2007, and idem, Errant Affirmations. On Kierkegaard's Religious Discourses, London: Bloomsbury, 2017. 